\title{
Provision of Teaching/Learning Resources in the EarlyChildhoodEducationCentres in Kakamega County, Kenya.
}

\author{
Dr.Emmily M. Sitati ${ }^{1}$ (corresponding author), Dr.Bota Kennedy ${ }^{2}$ and \\ Prof.Mwangi ndirangu ${ }^{3}$ \\ 1 Department of Education planning and Management, MasindeMuliro University of Science and Technology \\ Box 190 - 50100, Kakamega -
}

\begin{abstract}
The early childhood education sector in Kenya does not receive direct funding from the government like the primary and secondary sectors. This then calls for stakeholders to provide finances for procurement of teaching/learning resources and other resources. The purpose of this study was to establish the provision of teaching/learning resources in ECE in Kenya. The study adopted a descriptive survey design to investigate this in Kakamega County, Kenya. Purposive sampling was used to select 3 sub-counties (30\% of the population). Proportionate stratified random sampling was used to select $30 \%$ of the public and private ECEs to participate. Head teachers and one teacher from the selected each ECE participated in the study. However where more than one teacher was found in an ECE centre, simple random sampling through balloting was used to select the one to participate. The DEOs and DICECE Officers of the selected sub-counties were selected purposively to participate in the study. Structured questionnaires were used to collect data from the ECE head teachers and teachers, interview schedules from the DEOs and DICECE officers and observation schedules used to collect data on availability of teaching learning resources in the ECE centres. The instruments were validated through expert judgement and pilot-testing. Reliability was estimated using Cronbach's coefficient Alpha which was 0.80 and deemed adequate for the study. Both descriptive and inferential statistics were used to analyse data. The findings of the study revealedthatstakeholders had made good efforts to buy instructional materials in both the public and private ECE centres. The study recommends that the government should streamline ECE within the policy of free primary education and expand the school equipment production unit (SEPU) to institute ECE equipment and materials.
\end{abstract}

Key words:Teaching/learning resources, Early Childhood Education Centres, availability, adequacy 2Department of Educational Psychology, MasindeMuliro University of Science and Technology 3 Department of External studies and Media, Egerton University

\section{INTRODUCTION}

The early years of a child's life are a time when it acquires concepts, skills and attitudes that lay the foundation for lifelong learning. The Ministry of Education (2003) postulates that early childhood education programs play a crucial role in laying a foundation for primary and subsequent further education and character formation. Nasibi (2005) notes that, a poor start leads to deficiency in the final product of the education system in spite of the length of time spent in the school.John Dewey emphasized that the child's environment should be a source of his/her learningPlatz and Arellano (2011). He viewed children as co-constructors of their learning and saw them as active agents and participants in shaping their learning environment and experiences Wood and Attfield (2005). Pestalozzion the other hand believed that children learn well through activity, doing this using all their senses and interacting with both the physical and human environmentRoK (2009). Bandura (1977) a learning psychologist reiterates that behaviour is learnt from the environment through the process of observational learning (Mcleod, 2011). Froebel who is the founder of the concept of the kindergarten emphasized activity through play as a natural way of learning and that education should conform to the child's free atmosphere(Platz and Arellano 2011). Rousseau stressed on concrete learning, and learning by doing, emphasizing the use of concrete materials when teaching children (ROK, 2009).Maria Montessori who pioneered the integrated learning that catered for all the needs of the child stressed that education should help a child unfold his/her individuality and that each child should be helped and guided to grow and develop. She emphasized the use of concrete materials and showed that students with intellectual disabilitiescouldlearn (RoK 2009). Teaching learning resources form a centre of focus that attracts the attention of children during the learning process. They arouse the child's interest promoting the desire tolearn. KIE (2009) observes that teaching/learning materials supplement the description of concepts by the teacher thereby helping to break the monotony of explaining words and processes that seem difficult to the child. They also save on teaching time as they make explanation easier, stimulate children's imagination, promote accuracy in describing concepts, 
cultivate social skills when children interact and work together in groups using such resources and finally give the children an opportunity to learn through a variety of senses resulting into high retention of information and skill learned. TheUnited Nation Education Scientific and Cultural Organisation (2005) recommends that children should be allowed to explore the environment and be provided with concrete objects like pebbles so that they can manipulate them instead of using abstract number cards so as to stimulate and expand the child's learning potential. Early childhood education teachers should understand that their job is not to teach specific subject matter, but to stimulate and expand the child's learning potential. The best way to do this is to allow the children to explore the environment themselves and to provide them with concrete objects they can manipulate. Instead of using abstract number cards, for instance, the teacher can use concrete objects such as pebbles (UNESCO, 2005).The creation of a sustainable learning environment helps children who are slow learners to improve their academic performance (ShiunduandOmulando, 1992).

Ministry of Education (2003) observes that the school and class organisation should reflect the needs of the child. Aspects that are geared towards general teaching should be done through methods that allow the child to learn and experience the world around it. Play forms a very important aspect of learning and therefore it is paramount. The article recommends plenty of varied learning materials and equipment. These can provide a foundation for learning many concepts and widening a child's experiences. The room should be organised and arranged so that the needs and interests of children are met. UNESCO (2005) recommends that teaching/learning resources should be stored well to allow children participate in storing as well as taking care of them as this forms part of the learning. There is need for government to increase ECDE subsidy to cover more centres so as to improve provision of teaching/learning resources (Owiye, 2010).

A study by Murundu, IndoshiandOkwara (2010) on school based factors influencing implementation ofearly childhood development and education curriculum in Emuhaya district revealed that teaching and learning resources in ECDE centers wereinadequate in terms of both quality and quantity andsometimes teachers taught without them. Teachers who were interviewed indicated that they lacked time, money and skills to makeor buy them.Koech, Mwololo, BegiandMutweleli (2011) carried out a study on the factors influencing the selection of instructional resources for teaching pre-schools in Eldoret Municipality. The study sought to establish availability of instructional resources in the pre-schools and determine head teachers' attitudes and learners' characteristics that influenced the selection of these instructional resources in pre-schools. The study established that teaching experience, duration of the initial teacher training, the age of the teacher, the teaching methods employed, mastery of the content, motivation, level of education and attitude towards pre-school influenced the selection of instructional resources. The study further revealed that the head teachers' motivation, capacity to procure funds to buy instructional resources, and their knowledge of the value of instructional resources greatly influenced the selection of instructional materials acquired for the ECE institution. The age and entry behaviour of a pre-schooler, the number of children in a class, gender, pre-scholars' socio-economic backgrounds, their safety, ability (special need/normal children) and the language level also influenced the selection of instructional resources. Recommendations were made to ensure efficiency and effectiveness in material development. This included, more time to be given for in-service training of teachers and careful selection of instructional materials.Rotumoiand Too (2012) undertook a study on the influence of instructional resources available on the choice of teaching methodologies by pre-school teachers in Baringo District. The study concluded that there was a direct correlation between the choice of instructional methodology and availability of instructional resources. These findings provide strong evidence that instructional resources are useful as they facilitate learning of young children. Children are fascinated by the objects when used in childcentred approaches, which are recommended by KIE. However instructional resources may not be the only factor that influences the choice of methodology. Further studies suggest that the availability of instructional materials influences teachers' choice of instructional practices and learners success (Yi, 2006).Sackes, Trundle, Bettand O'Connell (2010) observed that the availability of science and nature corner was positively related to children's use of science equipment and participation in science related activities. When materials are available in the kindergarten classrooms, children are more likely to be engaged in science activities. This clearly emphasises that materials and resources are important in every activity area for effective learning in ECE centres.Pence and Schaffer (2006) examined the use of indigenous knowledge in ECE practices and policies. The study explored the role of play, song, proverbs, stories and their contribution to the development of ECE. The study established that teaching using play, song, proverbs and stories created a cultural contextwhich created a stronger link between home and school life. This is an important aspect of ECE education since children are integrated into their societies even when they are away from them because of migration, urbanization or modernization. They are able to learn their culture and this means the teaching/learning resources used should be able to assist the children trace their cultural roots. However, technology has deeply taken roots and the demands of the society require that all learners at all levels embrace technology rendering cultural and indigenous knowledge redundant and outdated (Pence and Schafer, 2006). 


\section{PROBLEM STATEMENT}

Early childhood programmes are supposed tostimulate a child's interests, assist a child's achievement, be motivating, fascinating and attention capturing. The programme is supposed to help a child develop holistically. Children learn well when they are actively engaged in the learning process. To achieve this, the ECE centres require adequate and appropriate teaching/learning materials. Most ECE centres in Kenya do not receive direct funding from the government and this then call for concerted efforts by all stakeholders to provide the required teaching/ learning resources. Depending on the centres' funding, the teaching/ learning resources vary and this means that there is no uniformity in provision of these resources. However, there is a need to have basic resources that can enhance the teaching/learning process in the ECE centres. It is against this background that the study sought to establish the availability of these teaching/learning resources in the ECE centres in Kakamega County.

\section{RESEARCH DESIGN}

The study adopted a descriptive survey design to investigate theprovision teaching/learning resources in ECEcentres in Kakamega County. The design described recorded, analysed and interpreted relationships or conditions, as they exist without manipulating variables (Kothari, 2003). The location of the study wasKakamega County, one of the forty- seven counties in Kenya with 11 administrative sub-counties. The area was selected for study because of the diversity of the county in terms of existence of urban and rural settings, a variety of socio-economic activities as well as being the largest county in Western region and the second largest county of Kenya. The poverty levels are high with $58 \%$ of the county's population living below poverty line. The location was easily accessible to the researcher.

\section{TARGET POPULATION AND SAMPLE SIZE}

The study targeted all the 1,820 (950 public and 870 private) ECE centres in the countywith total of 1,820 head teachers and 3571 teachers. All the 11 DEOs and 11 DICECE Officers in the county participated in the study. Purposive sampling was used to select 3 sub-counties in the county to participate in thestudy which was approximately $30 \%$ of the population (O'Connor, 2011).The sub-counties had both rural and urban settings therefore giving a variety of cases for comparison purposes. Three sub-counties with this dichotomy were Kakamega Central, Mumias and Likuyani. Proportionate stratified random sampling method was used to select the participating ECE centres from the selected sub-counties. Thirty percent (30\%) of the public and private ECEs were selected to give 62 public and 122 private ECEs participating in the study. Head teachers from each ECE participated in the study making a total of 62 and 122 head teachers from private and public ECE respectively. One teacher from the sampled ECE participated in the study. However where more than one teacher was found in an ECE centre, simple random sampling through balloting was used to select the one to participate. The DEOs and DICECE Officers of the selected sub-counties were selected purposively to participate in the study.

\section{DATA COLLECTION INSTRUMENTS}

Data was collected using structured questionnaires, an interview and observation schedule. Questionnaireswere used as they are time saving, confidential and there is no opportunity for interviewee bias (Kombo and Tromp, 2006). Questionnaires were used to collect data from the head teachers and ECE teachers. Open, closed and Likert questions were used to collect information from the respondents. Interview schedule was used to collect data from the DEOs and the District DICECE officers to give in-depth information. The interview method enabled the researcher to obtain more detailed information (Kothari, 2003). Mugenda and Mugenda (2003) observed that an interview schedule allows the respondents to freely respond to the questions and gives the researcher an opportunity to probe for answers. Questionnaires and interview schedules were developed with guidance of experts in research methodology and the research supervisors. Observation schedules were used to gather information on the teaching/learning resources. Observation schedules were used to record what the researcher anticipated to observe during data collection. Observation drew direct evidence of the eye witnessevents first hand (Mutai, 2000) and helped put the behaviour in context making it clearer and well understood. The investigator was able to observe directly and record aspects of the availability and use of teaching/ learning resources.

\section{VALIDITY AND RELIABILITY OF THE INSTRUMENTS}

Content validity was ensured by developing the instruments in such a way that all the concepts in the objectives were included in the instruments (MugendaandMugenda, 2003). Experts' judgement was also soughtfrom the experts in research methodology who verified the adequacy in coverage of the topic and ensure the questions were logically arranged and all the aspects were well covered. This ensured that the instruments yielded both face and content valid data. The same experts assisted in ensuring content and face validity. 
Reliability was ensured through piloting of the instruments and the results used to calculate the reliability of the questionnaires. Split half method was used to calculate a correlation coefficient after which Cronbach's coefficient Alpha was computed to determine how items correlated among themselves. Cronbach's alpha is a general form of the Kunder-Richardson (K-R) 20 which is based on the split half reliability of data from all possible halves of the instrument (Orodho, 2005). The method reduced the time required to compute a reliability coefficient in other methods as well as result in a more conservative estimate of reliability. A correlation coefficient of 0.80 was arrived at and accepted for use in this study.

\section{DATA COLLECTION AND ANALYSIS}

A permit from the National Council of Science and Technology and permission from the Director of Education to carry out the study were sought. The researcher then got the names of the ECE centres from the DEOs offices from which the required sample was selected using stratified random sampling. The researcher then proceeded to the centres where she sought audience with the head teachers. The teachers and the head teachers were then issued with the questionnaires separately after which the researcher collected data from through observation using the observation schedules. The researcher then checked the questionnaires if they were fully filled. If not fully filled the corresponding respondent was requested to fill the gaps as the researcher waited. This procedure took a maximum of two hours in a centre and proceeded until all the sampled centres were covered. This ensured $100 \%$ return rate as the researcher left with all the required data. Primary data was collected using questionnaires and interview schedules while secondary data was collected by use of observation schedules. Data was edited, organized in line with demographic aspects, groups and research questions and coded accordingly (Tromp, 2006).Qualitative data was organised in themes and reported using textual presentation. Quantitative data was coded and analysed by use of Statistical Package for Social Sciences (SPSS). Both descriptive and inferential statistics were used to analyse quantitative data. Findings were presented in frequency tables, charts and graphs as this easily communicate the research findings to majority of readersGay (2003).

\section{FINDINGS AND DISCUSSIONS}

The main objective was to establish the influence of the stakeholders in the provision of Teaching/learning resources in the ECE centres in Kenya. Teachers were asked to rate the quantity of the teaching /learning materials in their centre as stipulated in the Ministry of Education Service Standard Guidelines (RoK, 2006). The results were presented on Table 1:

Table 1: Availability of teaching/ learning resources.

\begin{tabular}{|l|c|c|c|c|}
\hline Teaching / learning materials & $\begin{array}{c}\text { Adequate } \\
\%\end{array}$ & $\begin{array}{c}\text { Fairly } \\
\text { adequate } \\
\%\end{array}$ & $\begin{array}{c}\text { Inadequate } \\
\%\end{array}$ & $\begin{array}{c}\text { Unavailable } \\
\%\end{array}$ \\
\hline ECDE KIE syllabus activity books and & 56.0 & 20.7 & 8.1 & 15.2 \\
\hline $\begin{array}{l}\text { Language and environmental } \\
\text { resources }\end{array}$ & 44.5 & 29.5 & 10.8 & 18.0 \\
\hline $\begin{array}{l}\text { Mathematics and } \\
\text { activity books and resources }\end{array}$ & 35.9 & 26.8 & 19.7 & 11.8 \\
\hline Science activity books and resources & 27.5 & 18.6 & 23.0 & 30.9 \\
\hline $\begin{array}{l}\text { Play, creative and manipulative } \\
\text { activity books and resources }\end{array}$ & 24.5 & 21.7 & 25.5 & 28.3 \\
\hline Wall charts & 38.6 & 10.8 & 23.4 & 27.2 \\
\hline Counting sticks/bottle tops & 26.2 & 37.1 & 21.2 & 15.5 \\
\hline Nature corner & 27.3 & 33.2 & 24.5 & 15.0 \\
\hline Building blocks & 41.3 & 27.2 & 12.0 & 19.5 \\
\hline Flash cards & & & \\
\hline Source: Field data & & & \\
\hline
\end{tabular}

Table 1 indicates that majority of the ECE centres had made attempts to procure the ECDE/ KIE syllabus as reported by $76.7 \%$ of the teachers. The ECE syllabus is an important curriculum document as it guides the implementation of the curriculum. The Early childhood development service standards guideline recommends the use of the approved KIE syllabus which puts a lot of emphasis on holistic learning. The ECE curriculum is important as it determines why a particular subject and activity should be taught and how it should be taught (BegiandKoech, 2010). Lack of the document implies that the teachers are not implementing the ECE thus; the aims of theeducation may not be realized. The syllabus contains both general and specific objectives and the 
content to be taught is spelt out in orderto guide the user. It is divided into three levels which are day care, preprimary 1 and pre-primary 2 (RoK, 2008). Availability and adequacy of teachers' activity guide books were alsoinvestigated. These included the language, mathematics and environmental, science, play, creative and manipulative activity books and resources. The results show that majority of the ECE centres had adequate and fairly adequate language, mathematics and environmental, and science activity books and resources as reported by $71.2 \%, 74.4 \%$ and $62.7 \%$ respectively. These findings agree with those of a study by Mwome (2005) whichindicated that ECE centres hadadequate teaching materials in each of theseactivity areas. Language teaching is very important to the ECE child. Language is a vehicle through which messages are transmitted from an individual to the other. Children are encouraged to express themselves freely and confidently. Through language teaching, children learn to speak clearly and fluently and develop their vocabulary (RoK, 2008). This can only be achieved if the teachers are well guided Acquisition of appropriate language teaching resources is therefore important (RoK, 2008).In ECE, mathematics skills are acquired through children interaction with their immediate environment by use of all their senses through games, poems, songs, rhymes and other play activities which interest the child (KIE 2009). It is during these early ages that children can develop interest in mathematics and develop positive attitudes towards mathematics, mathematical concepts and skills early enough. The teacher acquires content, concepts, skills, methods and approaches in teaching mathematics to young children. The mathematics activity book gives the teacher clear guidelines of imparting mathematics skills to the learners. It is therefore imperative that all centres have copies of these activity books (KIE, 2009). Small manipulative resources like sticks, stones, bottle top, pebbles and other physical materials can support young children's mathematical thinking and support quantitative learning in children (Perry andConroy, 1994). The teacher should therefore create a conducive learning environment where these materials are well displayed to promote autonomy for the mathematical thinking of the child and create confidence (UNESCO, 2005). Resources for teaching mathematics through play act as a bridge to teaching mathematic as observes Ngosike, (2003). Science and technology on the other hand are important indicators that can drive a country to achieve its technological dream reforming the economic development KIE, (2011). Skills, knowledge and attitudes in science are acquired at the early stages of schooling through manipulative activities such as feeling, observing, listening. An environment that encourages children to work independently on problems, projects and experiment that interest the child is vital, (KIE 2008). The teacher needs to organise relevant materials for learning of science and provide the space as he/she supervises. The teacher therefore requires guidelines to do this and this is well stipulated in the science activity book (KIE, 2009). The availability of these activity books in the ECE centres is very crucial as it guides the teacher to prepare the learning environment for the learning of science (KIE, 2009). Sackes et al (2010) puts emphasis on the availability of science and nature corner as it positively relates to children's use of science equipment and participation in cooking activities. In addition, appropriate science materials and resources in the kindergarten classrooms make children more likely to be engaged in science activities unleashing their potentials in innovativeness and creativity.

Responses on the availability and adequacy of play and creative and manipulative activity books and materials indicated that majority of the centres either had inadequate or lacked the resources completely as reported by $53.9 \%$ of the teachers. This included books and resources on creative, social, life skills, music and movement and outdoor activity, drawing, crayons and plastacine. Creative activity books enable the teacher to help children develop their imagination, creativity and personality. The teacher is able to guide children on how to use of play and manipulative activities as a medium of expressing themselves to their immediate environment RoK, (2006).

Play, creative and manipulative activity books and resources are instrumental in guiding the teacher on how to impart survival skills in children such as how to relate and co- exist with others in the society. Further, through drawing and colouring, children develop expressive and creative skills (KIE, 2011). When children are not provided with these resources then they cannot learn to express themselves effectively, thus their talents and potential are not exploited fully. The implication of this finding is that creative and manipulative activities are poorly implemented as teachers lacked guidelines, supporting materials and resources in majority of the centres impacting negatively on the learners' skill acquisition. There could be a possibility that teachers may ignore this aspect due to lack of these materials. It is therefore clear that most ECE centres were endowed with sufficient copies of most of the activity books contrary to the findings of Thomson et al (2009) who observed that most ECE centres lacked activity books to guide teachers in implementing the ECE curriculum.

The Table further shows that majority of the ECE centres had made efforts to acquire nature corners, $(63.3 \%)$, building blocks $(60.5 \%)$ and flash cards $(68.5 \%)$ as indicated by the adequate and fairly adequate response by the respondents on these items. However $53.8 \%$ and $50.6 \%$ reported that they either had inadequate or lacked the wall charts and counting sticks /bottle tops respectively. Wall charts are meant to communicate to the children and continuously remind them on what they learn as they are able to see different images, numbers and figures and relate to what the teacher teachers them making learning real and enjoyable (KIE, 2008). The wall charts can be produced locally by the teachers or purchased from publishers and printers. They form an 
important aspect of skills acquisition in ECE. The finding is an indication that there is no paradigm shift from the traditional methods of teaching to the modern child friendly methodology through the "talking walls" which enhances learning and sustains the interest of the learners. The counting sticks/bottle tops are the cheapest locally available materials that can easily be assembled by both the children, parents and teachers (NACECE, 1995). One could imagine that given the nature of these resources the ECE centres could have them in excess which was not the case. The interpretation is that stakeholders had made efforts to provide most of the teaching//learning resources an indication of their commitment in improving services at the ECE centres. The government's ECD capitation grant for 2012/2013 allocated more than half of the money disbursed to the centres to purchase of instructional materials and specifically ECD activity books (MoE, 2013). This in away may have contributed to the adequacy of most activity books in the centres.

DEOs and DICECE officers were asked through an interview to give their views on the influence of stakeholders on provision of teaching/learning resources. The results are presented on Table 2:

Table 2: Stakeholders roles in provision of teaching/learning resources

\begin{tabular}{|l|c|c|c|c|}
\hline \multicolumn{1}{|c|}{ Responses } & \multicolumn{2}{|c|}{ DEOs } & \multicolumn{2}{c|}{ DICECE officers } \\
\hline $\begin{array}{l}\text { ECE centres developed teaching/learning } \\
\text { resources }\end{array}$ & $\mathrm{f}$ & 33.3 & 2 & 66.7 \\
\hline $\begin{array}{l}\text { Teaching/learning resources are vital in } \\
\text { teaching ECE children }\end{array}$ & 3 & 66.7 & 3 & 66.7 \\
\hline Centres had syllabus aad adequate & 2 & 66.7 & 2 & 66.7 \\
\hline $\begin{array}{l}\text { ECE centres had } \\
\text { teaching/learning materials }\end{array}$ & 2 & 66.7 & 2 & 66.7 \\
\hline $\begin{array}{l}\text { ECE centres had appropriate Teaching/ } \\
\text { learning materials. }\end{array}$ & 2 & 33.3 & 1 & 33.3 \\
\hline
\end{tabular}

Source: Field data

There were disparities in the views of the DEOs and the DICECE officers on the role of stakeholders in provision of teaching/learning resources. Two DEOs $(66.7 \%)$ were of the view that teaching learning resources were vital in teaching/learning in ECE centres, ECE centres had the KIE syllabus and that most ECE had adequate teaching/learning resources. However only one (33.3\%) of the DEOs reiterated that the ECE centres had developed teaching/learning resources and that although the ECE centres had developed teaching/learning material, they were not appropriate in terms the children's age and of assisting the teacher achieve the learning outcome. The DICECE officers who are constantly in touch with the ECE centres were of the view that ECE centres had developed teaching/learning resources, Teaching/learning resources were vital in teaching ECE children, ECE centres had KIE syllabus and ECE centres had adequate teaching/learning materials as reported by $66.7 \%$ of them. However, they too were of the view that despite the adequacy of teaching/learning materials, the materials were inappropriate for the children and for teaching at the ECE centres. Only $33.3 \%$ of the DICECE officers agreed to this. The DICECE officers whose role included training teachers and other stakeholders on development of the resources admitted that they had not done much in that area due to resource constrains at their level. Teaching/learning materials and resources are therefore very important in every activity area for effective learning in ECE centres. Kenya Institute of Education, (2009) support use of teaching/learning materials as they supplement the descriptive of concept by the teacher as it help break the monotony of explaining vocabulary and process that seems difficult to the children. This is emphasised by Rogers (1999) who stated that blocks play support mathematics education. UNESCO (2005) advices that use of concrete objects in teaching children helps stimulate and expand the child's learning potential. It therefore implies that with these resources in the ECE centre, the children are able to acquire mathematical skills and knowledge through manipulate the blocks. Through the use of appropriate resources, ECE centres can lay a foundation for future engineers, architectures, economists, mathematicians and other professionals who require high level mathematical skills. Perry and Conroy (1994) argue that mathematical instruction can be enhanced when children interactwith water, sand and are involved indramatic play. These are cheap and readily available resources that can be easily mobilized by the stakeholders. Teachers therefore require the skills and knowledge of assembling and usingthese resources for the best output. This is well articulated in the teachers' activity books. From the findings, it is evident that majority of the ECE centres had were reasonably provided for with teaching learning resources. Other studies by Waithera (2004) in Thika district and indicated that both the public and private ECE centres had a variety of teaching learning resources though not appropriate and adequate and Murundu et al (2010) who indicated that most ECE centres had inadequate/lacked the necessary teaching/learning resources. This therefore reveals disparities in resources allocation by ECE stakeholders in different counties. Teaching learning materials form a very important aspect of teaching/learning in ECE as they 
make learning real, create many opportunities to learn and teach and give a variety of experiences to a child. They stimulate learning (Waithera, 2004) and healthy growth and development of children. Children learn better when they see, touch, feel or taste. This is supported by Fredrick Frobel (1782-1852) and Maria Montessori who emphasised use of teaching learning materials in helping children learn by developing all their senses. The national ECD policy framework puts the burden of providing teaching/learning materials and resources to all stake holders (ROK, 2006). Further other studies reveal that the availability of instructional materials influences teachers' choice of instructional practices and learners success (Yi, 2006). This therefore means that majority of the stakeholdershave played their roles in providing the some teaching/learning resourcesrequired for effective implementation of ECE programs. However there is need for all the stakeholders to take up their sole responsibility of equipping all the ECE centres with adequate teaching learning resources. Concerted efforts by all stakeholders are required to address the inadequacy of teaching/learning resources in some ECE centres which in turn impact on the quality of services offered to the ECE children. Stakeholders need to be convinced that these resources form an important aspect of learning in ECE. UNESCO, (2005) agrees that concrete evidence is paramount in convincing the parents as well as teachers that play is the best medium through which young children develop, learn and prepare for their future. It further recommends that children should be allowed to explore the environment and be provided with concrete objects like pebbles so that they can manipulate them instead of using abstract number cards so as to stimulate and expand the child's learning potential. Early childhood education teachers should stimulate the child (Waithera, 2004) and expand the child's learning potential by ensuring that the learning environment is child friendly and allows the children to explore the environment forthemselves. The teacher should also provide them with concrete objects they can manipulate.Shiundu and Omulando (1992) support the concept of creating a learning environment that helps children who are slow learners to improve their academic performance. Matear (1990) relatesprovision ofhigh quality services to children in ECE learning with adequacy of teaching/learning resources which he observes are adequately provided in private ECE centres. Parents of thesecentres pay slightly higher levies to the centres as compared with those in public ECE centres. This is supported by McEwan (2001) who reiterates that children from well off families attend private ECE centreswhich provide quality education and havehigh parental support and care. These centres provide adequate teaching learning resources enabling the children to develop their maximum potential. Fleer andRaban (2005), and Rogers (1999) argue that anenvironment that is rich in language and mathematics resources is likely to promote children's literacy and numeracy skills. Early Childhood Service Standard Guidelines and NACECE (1995) emphasize partnership between the teachers, parents and the other stakeholders in the provision of adequate teaching/ learning materials. TheKoech Report recommendstheuse of locally available materials which are cheap, and children can identify them more easily (RoK, 1999).

\section{SUMMARY AND CONCLUSIONS}

With regard to provision of teaching/learning resources by stakeholders, the findings of the study revealed that main stakeholders in provision of teaching/ learning resources were the parents who did this through the fees paid to the ECE centres. Stakeholders in both private and public ECE centres had provided adequate and fairly adequate teaching learning resources like ECDE KIE syllabus, language, mathematics, environmental and science activity books, nature corners, building blocks and flash cards. In many ECE centres, stakeholders were unable to provide adequate teaching/learning resources for play, creative, manipulative and outdoor activities as well as wall charts and counting sticks/ bottle tops. The study concluded that stakeholders had attempted to provide some of the teaching/learning resources in the ECE centres. The study recommended that stakeholders should strike a balance between paying teachers' salaries and providing all the necessary teaching/ learning resources to the ECE centres. Further locally available teaching /learning resources should be availed by stakeholders and adopted for use in the centres to cut on cost.

\section{REFERENCES}

[1] Bandura, A.J. (1977). Social learning Theory. Englewood Cliffs, NJ: Prentice Hall.

[2] Katheri, C. R. (2003). Research Methodology: Methods and Techniques. Wishwa: Prakashan Printers.

[3] Kenya Institute Education. (1999). Guideline for Early Childhood Education. Nairobi: NACECE.

[4] Kenya Institute of Education. (2006). Teacher certificate in ECDE syllabus. Nairobi: KIE.

[5] Kenya Institute of Education. (2009). Mathematics and environmental activities. Nairobi: Kenya Literature Bureau.

[6] Kenya Institute of Education. (2011). Play and creative activities. Nairobi: Kenya Literature Bureau.

[7] Kenya Institute of Education. (2011). Language and science activities. Nairobi: Kenya Literature Bureau.

[8] Kipkorir, L. I., andNjenga, A. W. (1993). A case study of early childhood care and education in Kenya. Paper prepared for the EFA Forum 1993, New Delhi, 9 - 10 September 1993. 
[9] Koech, B.G. (2011). Parent- Teacher partnership for editing Pre-school children's education in UasinGishu District, Kenya. Moi University. Unpublished M.E.D. Thesis.

[10] Koech, B.G, Mwololo, J.N., Begi , N. andMutweleli, S.M. (1011) Pre-school teachers' knowledge and attitude towards use of Visual media in Institutional delivery in Kibwezi District, Kenya. Journal of Research in Education andsociety 2 (1), pp 97- 105.

[11] Kombo, D. K., and Tromp D. A. (2006). Proposal and Thesis Writing. Nairobi: Pauline's Publications Africa.

[12] Kombo, J. andGogo, J. G. (2004). The role of the church in the provision of Early Childhood Education in Nairobi, Kenya. Nairobi: Daystar University Centre for Research, publication and Consultancy.

[13] Matear, A. (1990). Barriers to Equitable Access in Higher Education Policy and Practices in Chile since 1990. Chile

[14] McEwan, P. J. (2001). The Effectiveness of public, catholic and non-religious private schools in Chile's voucher system. Journal of Education Economic Vol. 9 pp 103-128.

[15] Mcleod, S.A. (2011).Albert Bandora social learning theory. Retrieved on 13/11/2012. From http// www.simplpsycholog.org/bandora.html.

[16] Ministry of Education. (2013). Disbursement of ECD capitation grants. PE. 18/37/VOL.II/20

[17] Mugenda, M.O., andMugenda, G. A. (2003). Research Methods; Quantitative and Qualitative Approaches. Nairobi: Acts Press.

[18] Murundu, Z. O., Indoshi, F.C. andOkwara, O. M. (2010). School Based Factors Influencing Implementation of Early Childhood Development and Education curriculum. Education. Research Journals Vol.1 (9) pp.382-389.Retrieved on $6{ }^{\text {th }}$ Sep 1012from http:// www.interesjournals. Org/ER.

[19] Mutai, B.K. (2000). How to write quality research proposal: A complete and simplified Recipe. Scotland: Thelley Publisher.

[20] Nasibi, M. W., (2005). Early Childhood Education- Teaching at Pre-school. Nairobi: Nehema publishers.

[21] Orodho, J.A. (2005). Elements of education and social sciences research methods. Nairobi; Masola Publisher.

[22] Owiye, J. (2010) Management of resources in ECDE centres and its implications on quality of ECDE in Bungoma East District. Unpublished M.Ed thesis. MasindeMuliro University of Science and Technology.

[23] Pence, A., and Schafer. J. (2006). Indigenous knowledge and early childhood in Africa. The Early Childhood Development Virtual University: Journal for Education in International Development2:3.Retrieved from www.equip123. Net/jeid/articles/4/indigenous and the ECDVU on 23/9/2011

[24] Perry, B.,and Conroy, J. (1994). Early Childhood and Primary mathematics: A participative text for teachers. Sydney Australia. Harcourt Brace.

[25] Platz, D., \& Arellano, J. (2011). Time tested early childhood theories and practices. Education,

[26] 132(1), 54-63.

[27] Raban, B.,and Fleer, M. (2005). DEST Early Childhood learning resource. Literacy and Numeracy, a review of the literature.

[28] Rabie, T., and Curtis, V. (2006).Hand washing and risk of respiratory infections: A quantitative review. Tropical Medicine Int. Health Vol.11 pp 258-267

[29] Republic of Kenya. (1999).Totally Integrated Quality Education and Training (TIQET). Nairobi. Government Printers.

[30] Republic of Kenya. (2005a).Kenya Education sector support program- 2005-2010. Government printers. Nairobi.

[31] Republic of Kenya. (2005b). Education Sector Report 2008.Realizing Vision 2030 goals through Effective and Efficient Public Spending. Nairobi: Government Printers.

[32] Republic of Kenya. (2000). Guidelines for Early Childhood Development in Kenya. Nairobi: Kenya Institute of Education.

[33] Republic of Kenya. (2006a). National Early Childhood Policy Framework. Nairobi: Government Printer.

[34] Republic of Kenya. (2006b). Early Childhood Development Service Standard Guidelines for Kenya. Nairobi: Government Press.

[35] Republic of Kenya. (2008a). Handbook for Early Childhood development and Education Syllabus. Nairobi: KIE.

[36] Republic of Kenya. (2008b). Early Childhood Development and Education Syllabus. Nairobi: K.I.E.

[37] Republic of Kenya. (2009). Philosophical, sociological and Historical foundations. Diploma Module. Nairobi: Kenya Institute of Education.

[38] Republic of Kenya. (2009). Child growth and Development Module ID002: Nairobi. KISE 
[39] Republic of Kenya. (2005). Background Report of Kenya for UNESCO/OECD policy review Project. Nairobi: Government Printers.

[40] Rogers, A. (1999). Children and Block Play: mathematical Learning in Early Childhood. The next generation, AAMT. Australia: Adelaide.

[41] Rutomoi, J. and Too, J. K. (2012). Factors influencing the choice of approaches used by pre-school teachers in Baringo County, Kenya. International Journal of Academic Research in programme development, 1 (2) ISSN: 2226 - 6348 pp (177 - 187).

[42] Sackes, M., Trundle, K., Bett, R. andO'connell, A. (2010). The influence of early childhood science experience in kindergarten on child's immediate and later science achievement: Evidence from the Early Childhood Longitudinal Study. Journal of Research in Science Teaching. Vol.48 No.2.pp.217-235

[43] Shiundu, J.S., andOmulando, S. J. (1992). Curriculum: Theory and Practice in Kenya. Nairobi: Oxford University Press.

[44] UNESCO Association Report. (2005). Challenges of Implementing Free Primary Education in Kenya. Nairobi: UNESCO.

[45] UNESCO, (2005). Education resource projection in the context of sector wide development planning. Paris. UNESCO.

[46] Waithera, N. R. (2004). Factors that affect management of ECD centres in Thika District, Kenya. Unpublished M.Ed. thesis. University of Nairobi. Kenya.

[47] Wood, E., \&Attfield, J. (2005). Play, learning and the early childhood curriculum (2nd ed.).

[48] London: Paul Chapman.

[49] Yi, L. Y. (2006). Classroom organization: understanding the context in which children are expected to learn. Early childhood education journal. 34(1), PP 37-43. 